\section{Dental arch dimensions and tooth wear in two samples of children in the 1950s and 1990s}

\author{
M. Camporesi, ${ }^{1}$ A. Marinelli, ${ }^{2}$ G. Baroni ${ }^{3}$ and E. Defraia ${ }^{4}$
}

IN BRIEF

- Increase understanding of the pattern of tooth abrasion and malocclusion in mixed dentition.

- Provides insight into the relationship between contraction of upper arch and dental interferences with malocclusions.

- Discusses the role of environmental factors in the genesis of malocclusions.

Aim The objective of this study was to compare the degree of tooth wear in posterior deciduous teeth and the dental arch dimensions in the mixed dentition in two modern samples living in the same geographic area and separated by almost 35 years. Methods Dental casts of a group of subjects born between 1953 and 1959 were compared with subjects born between 1990 and 1998. The evaluation of tooth wear scores and measurements for posterior and anterior arch segments, intermolar and intercanine width, and mesiodistal size of incisors were taken. The available anterior space in both arches and the posterior and anterior transverse dimensions were calculated. Groups were compared using a nonparametric test (Mann-Whitney U-test) for independent samples $(\mathrm{P}<0.05)$. Results The results show that both boys and girls of the $1990 \mathrm{~s}$ showed significantly smaller maxillary intermolar width when compared with the 1950s. Posterior transverse interarch discrepancy was significantly minor in girls of the 1990s. The comparison of abrasion showed significant differences between the two groups for all examined teeth which appeared to be more abraded in the 1950s group. Conclusions This association can partially explain the greater risk of developing malocclusions in contemporary children compared with children living 35 years before.

\section{INTRODUCTION}

Malocclusion includes the malposition of individual teeth, discrepancies between tooth and jaw size and malrelations of the dental arches in the sagittal, transverse, and vertical dimensions. ${ }^{1}$

A high prevalence of malocclusion was reported in many contemporary cohorts while populations living in primitive conditions were often described with good dental alignment and with an almost correct occlusion. ${ }^{2,3}$

These observations were the basis to indicate malocclusion as a 'disease of civilisation'. A dramatic difference is demonstrated in individuals with a similar genetic pool in the change from a sociotechnologically preindustrial situation to another influenced by industrialisation. ${ }^{4}$ Secular trends in occlusal patterns were

\footnotetext{
${ }^{*}-4$ Department of Orthodontics, University of Florence, Florence, Italy

${ }^{*}$ Correspondence to: Dr Andrea Marinelli, Department of Orthodontics, University of Florence, Via del Ponte di Mezzo 46-48, 50127 Florence, Italy

Email:a_marinelli@yahoo.com
}

\section{Online article number E24}

Refereed Paper - accepted 23 March 2009

DOI: $10.1038 /$ sj.bdj.2009.960

${ }^{\circ}$ British Dental Journal 2009; 207: E24 reported in several populations between ancient and modern subjects. Differences were reported also in groups of the same century separated by almost 30 years. ${ }^{5-9}$

Modifications of the environment surely have a major role in causing a severe increase in the prevalence of malocclusions., ${ }^{2,3}$ Changes in dietary habits ${ }^{4}$ and a greater prevalence of respiratory pathologies in the last decades ${ }^{6}$ were held responsible for a progressive increase in the prevalence of malocclusions. The decrease in masticatory performance caused by the widespread use of processed food could be responsible for inadequate wear of deciduous teeth along with underdeveloped jaws. Dental interferences, forced guidance of the mandible and an incorrect position in both the sagittal or transverse planes can result in a lack of physiological changes in the dental arches. ${ }^{10,11}$

The aim of this study is to compare the dental arch dimensions and the degree of occlusal tooth wear in the mixed dentition (Fig. 1) of two modern samples living in the same geographic area and separated by almost 35 years: a group of subjects born in the 1950s and another group born in the 1990s, in order to investigate the biological bases of malocclusions.

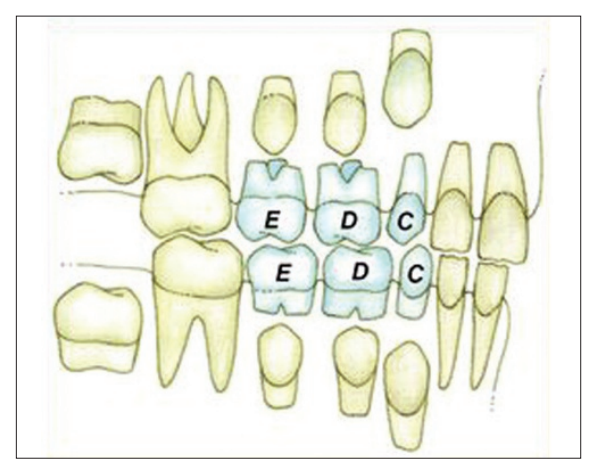

Fig. 1 Mixed dentition at about nine years. At this stage the following dental groups are present: permanent maxillary and mandibular first molars; permanent maxillary and mandibular central and lateral incisors; primary maxillary and mandibular second molars (E), first molars (D) and canine (C)

\section{SUBJECTS}

The 1950s group (50sG) with 100 subjects ( 52 boys and 48 girls) derived from the records of patients who were first observed at the Department of Orthodontics of the University of Florence, Italy, in the 1960s. All subjects were born between 1953 and 1959. The mean age of the 50sG was seven years and 11 months \pm eight months. The 50sG exhibited 43 subjects with Class I, 47 with Class II, and 10 with Class III malocclusions. 
The 1990s group (90sG) with 100 subjects ( 52 boys and 48 girls) derived from patients observed at the same department between 1996 and 2003. These subjects were born between 1990 and 1998, and they presented Class I (37), Class II (61), and Class III (2) malocclusions. The mean age of the 90sG was eight years and five months \pm 13 months.

The following inclusion criteria were adopted for both groups:

1. Availability of detailed clinical files

2. Availability of good quality dental casts

3. Absence of any previous orthodontic treatment

4. Absence of bruxism

5. Absence of missing teeth, dental traumas, dental anomalies, deep caries, restorations, pedodontic crowns

6. Availability of panoramic radiographs

7. Absence of prolonged sucking habit extending over four years of age

8. No ancestors of foreign origin

9. Absence of any major dentofacial anomaly (cleft lip and palate or others).

Panoramic radiographs were examined to control the absence of dental anomalies, deep caries, restorations and pedodontic crowns.

The sample utilised for the evaluation of the dental arch dimensions in mixed dentition was reduced to 83 subjects (39 boys and 44 girls) from the 1950 s and to 84 (38 boys and 46 girls) for the subjects from the 1990s, because the cases without complete eruption of the first molars were excluded.

The mean age of the 50sG was eight years and three months \pm 15 months for boys and seven years and 11 months \pm 12 months for girls.

\section{METHODS}

Two of the authors (MA and BG) evaluated the dental casts of the two groups simultaneously in the same room and in the same lighting conditions. They were blinded with regard to which group the dental casts belonged. On the basis of the degree of abrasion a variable score from 0 to 3 was assigned to posterior teeth, according to the method described by Knight et al. ${ }^{12}$ (Fig. 2).

- Score 0: no obvious wear facets in enamel, occlusal/ incisal structure intact

- Score 1: marked wear facets in enamel,
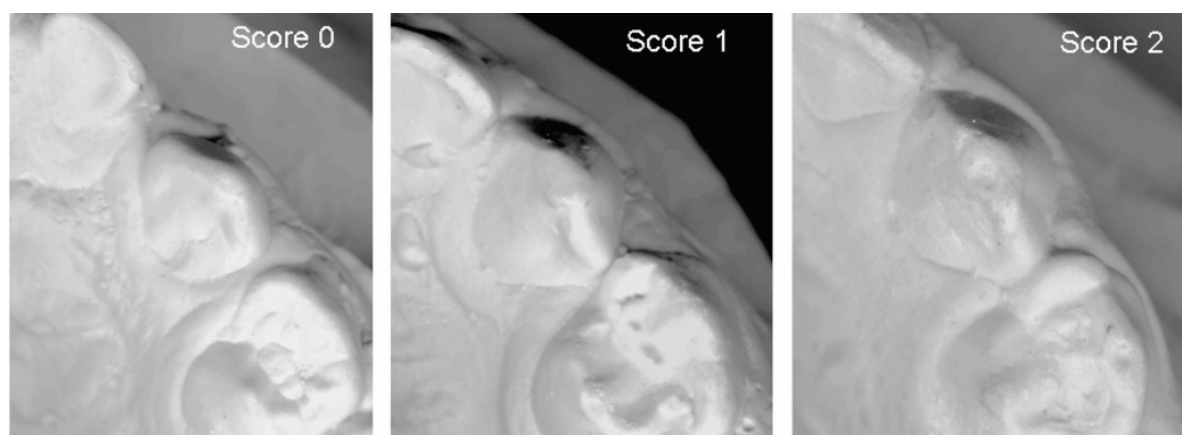

Fig. 2 Tooth wear score method (Knight et $a l_{.}{ }^{12}$ ) Score 0: no obvious wear facets in enamel, occlusal/incisal structure intact; Score 1: marked wear facets in enamel, occlusal/incisal structure altered; Score 2: wear into dentine, occlusally/incisally exposed dentine or occlusal/ incisal shape changed in shape (or both)

\begin{tabular}{|c|c|c|c|c|c|c|c|c|c|}
\hline \multirow[b]{2}{*}{ Tooth wear score } & \multicolumn{4}{|c|}{$50 \mathrm{sG}$} & \multicolumn{5}{|l|}{ 90sG } \\
\hline & 0 & 1 & 2 & 3 & 0 & 1 & 2 & 3 & \\
\hline Right C maxillary & 0 & $\begin{array}{l}2 \\
(3.8 \%)\end{array}$ & $\begin{array}{l}28 \\
(52.8 \%)\end{array}$ & $\begin{array}{l}23 \\
(43.4 \%)\end{array}$ & $\begin{array}{l}1 \\
(2 \%)\end{array}$ & $\begin{array}{l}10 \\
(20 \%)\end{array}$ & $\begin{array}{l}33 \\
(66 \%)\end{array}$ & $\begin{array}{l}6 \\
(12 \%)\end{array}$ & $* * *$ \\
\hline Right D maxillary & 0 & $\begin{array}{l}8 \\
(15.1 \%)\end{array}$ & $\begin{array}{l}44 \\
(83 \%)\end{array}$ & $\begin{array}{l}1 \\
(1.9 \%)\end{array}$ & $\begin{array}{l}1 \\
(2 \%)\end{array}$ & $\begin{array}{l}22 \\
(44 \%)\end{array}$ & $\begin{array}{l}27 \\
(54 \%)\end{array}$ & 0 & $* * *$ \\
\hline Right E maxillary & 0 & $\begin{array}{l}25 \\
(47.2 \%)\end{array}$ & $\begin{array}{l}28 \\
(52.8 \%)\end{array}$ & 0 & $\begin{array}{l}5 \\
(10 \%)\end{array}$ & $\begin{array}{l}32 \\
(64 \%)\end{array}$ & $\begin{array}{l}13 \\
(26 \%)\end{array}$ & 0 & ** \\
\hline $\begin{array}{l}\text { Right maxillary } \\
\text { segment }(C+D+E)\end{array}$ & 0 & 35 & 100 & 24 & 7 & 64 & 73 & 6 & $* * *$ \\
\hline Left $\mathrm{C}$ maxillary & 0 & $\begin{array}{l}3 \\
(5.7 \%)\end{array}$ & $\begin{array}{l}30 \\
(56.6 \%)\end{array}$ & $\begin{array}{l}20 \\
(37.7 \%)\end{array}$ & $\begin{array}{l}1 \\
(2 \%)\end{array}$ & $\begin{array}{l}12 \\
(24 \%)\end{array}$ & $\begin{array}{l}33 \\
(66 \%)\end{array}$ & $\begin{array}{l}4 \\
(8 \%)\end{array}$ & $* * *$ \\
\hline Left D maxillary & 0 & $\begin{array}{l}8 \\
(15.1 \%)\end{array}$ & $\begin{array}{l}45 \\
(84.9 \%)\end{array}$ & 0 & $\begin{array}{l}1 \\
(2 \%)\end{array}$ & $\begin{array}{l}18 \\
(36 \%)\end{array}$ & $\begin{array}{l}31 \\
(62 \%)\end{array}$ & 0 & ** \\
\hline Left E maxillary & 0 & $\begin{array}{l}25 \\
(47.2 \%)\end{array}$ & $\begin{array}{l}28 \\
(52.8 \%)\end{array}$ & 0 & $\begin{array}{l}1 \\
(2 \%)\end{array}$ & $\begin{array}{l}38 \\
(76 \%)\end{array}$ & $\begin{array}{l}11 \\
(22 \%)\end{array}$ & 0 & *** \\
\hline $\begin{array}{l}\text { Left maxillary } \\
\text { segment }(C+D+E)\end{array}$ & 0 & 36 & 103 & 20 & 3 & 68 & 75 & 4 & $* * *$ \\
\hline Right C mandibular & 0 & $\begin{array}{l}7 \\
(13.2 \%)\end{array}$ & $\begin{array}{l}29 \\
(54.7 \%)\end{array}$ & $\begin{array}{l}17 \\
(32.1 \%)\end{array}$ & $\begin{array}{l}1 \\
(2 \%)\end{array}$ & $\begin{array}{l}13 \\
(26 \%)\end{array}$ & $\begin{array}{l}34 \\
(68 \%)\end{array}$ & $\begin{array}{l}2 \\
(4 \%)\end{array}$ & *** \\
\hline Right D mandibular & 0 & $\begin{array}{l}6 \\
(11.3 \%)\end{array}$ & $\begin{array}{l}46 \\
(86.8 \%)\end{array}$ & $\begin{array}{l}1 \\
(1.9 \%)\end{array}$ & 0 & $\begin{array}{l}13 \\
(26 \%)\end{array}$ & $\begin{array}{l}37 \\
(74 \%)\end{array}$ & 0 & * \\
\hline Right E mandibular & 0 & $\begin{array}{l}17 \\
(32.1 \%)\end{array}$ & $\begin{array}{l}36 \\
(67.9 \%)\end{array}$ & 0 & $\begin{array}{l}1 \\
(2 \%)\end{array}$ & $\begin{array}{l}20 \\
(40 \%)\end{array}$ & $\begin{array}{l}29 \\
(58 \%)\end{array}$ & 0 & NS \\
\hline $\begin{array}{l}\text { Right mandibular } \\
\text { segment }(C+D+E)\end{array}$ & 0 & 30 & 111 & 18 & 2 & 46 & 100 & 2 & $* * *$ \\
\hline Left $C$ mandibular & 0 & $\begin{array}{l}8 \\
(15.1 \%)\end{array}$ & $\begin{array}{l}31 \\
(58.5 \%)\end{array}$ & $\begin{array}{l}14 \\
(26.4 \%)\end{array}$ & 0 & $\begin{array}{l}13 \\
(26 \%)\end{array}$ & $\begin{array}{l}33 \\
(66 \%)\end{array}$ & $\begin{array}{l}4 \\
(8 \%)\end{array}$ & ** \\
\hline Left D mandibular & 0 & $\begin{array}{l}8 \\
(15.1 \%)\end{array}$ & $\begin{array}{l}45 \\
(84.9 \%)\end{array}$ & 0 & 0 & $\begin{array}{l}12 \\
(24 \%)\end{array}$ & $\begin{array}{l}38 \\
(76 \%)\end{array}$ & 0 & NS \\
\hline Left E mandibular & 0 & $\begin{array}{l}15 \\
(28.3 \%)\end{array}$ & $\begin{array}{l}38 \\
(71.7 \%)\end{array}$ & 0 & 0 & $\begin{array}{l}24 \\
(48 \%)\end{array}$ & $\begin{array}{l}26 \\
(52 \%)\end{array}$ & 0 & * \\
\hline $\begin{array}{l}\text { Left mandibular } \\
\text { segment }(C+D+E)\end{array}$ & 0 & 31 & 114 & 14 & 0 & 49 & 97 & 4 & ** \\
\hline Total & 0 & 132 & 428 & 76 & 12 & 227 & 345 & 16 & $* * *$ \\
\hline
\end{tabular}

occlusal/incisal structure altered

- Score 2: wear into dentinee, occlusally/incisally exposed dentinee or occlusal/incisal shape changed in shape (or both)
- Score 3: extensive wear into dentinee, more than $2 \mathrm{~mm}^{2}$ of occlusally/ incisally exposed dentinee, and an occlusal/incisal totally lost structure, locally or generally. 
The degree of tooth wear on the maxillary and mandibular primary canines, the first primary molars and the second primary molars was calculated because tooth abrasion has a faster evolution on primary teeth, ${ }^{13}$ which should present physiologically reduced enamel width. ${ }^{14}$

The recorded data for the two groups were organised for statistical evaluation as follows: degree of abrasion of single teeth and degree of abrasion of single posterior segments of the dental arch (maxillary and mandibular posterior segments, each one consisting of the primary canine, the first primary molar and the second primary molar).

The following measurements were taken for maxillary and mandibular arch on dental casts using a sliding caliper:

1. Posterior segment (right and left): the distance between the mesial surface of the first permanent molar and the mesial surface of the primary canine

2. Anterior segment (right and left): the distance between the mesial surface of the primary canine and the mesial surface of the permanent central incisor

3. Mesiodistal size of each permanent incisor

4. Interincisal midline diastema

5. Available space, calculated as the sum of anterior segments and interincisal midline diastema minus the sum of the mesiodistal sizes of the teeth

6. Maxillary intermolar width: distance between the central fossae of right and left first maxillary molars

7. Mandibular intermolar width: distance between the tips of the distobuccal cusps of right and left first mandibular molars

8. Posterior transverse interarch discrepancy (PTID): difference between maxillary and mandibular intermolar widths

9. Maxillary intercanine width: distance between the mesial margin of right and left maxillary primary canine

10. Mandibular intercanine width: distance between the tips of the cusps of right and left primary canine. If the cusp tips were abraded, the assumed centre of the abraded area was used

11. Anterior transverse interarch

\begin{tabular}{|c|c|c|c|c|c|c|c|c|c|}
\hline \multirow[b]{2}{*}{ Tooth wear score } & \multicolumn{4}{|l|}{$50 \mathrm{sG}$} & \multicolumn{5}{|l|}{$90 s G$} \\
\hline & 0 & 1 & 2 & 3 & 0 & 1 & 2 & 3 & \\
\hline Right C maxillary & $\begin{array}{l}1 \\
(2.1 \%)\end{array}$ & $\begin{array}{l}7 \\
(14.9 \%)\end{array}$ & $\begin{array}{l}26 \\
(55.3 \%)\end{array}$ & $\begin{array}{l}13 \\
(27.7 \%)\end{array}$ & $\begin{array}{l}1 \\
(2 \%)\end{array}$ & $\begin{array}{l}14 \\
(28 \%)\end{array}$ & $\begin{array}{l}34 \\
(68 \%)\end{array}$ & $\begin{array}{l}1 \\
(2 \%)\end{array}$ & $* *$ \\
\hline Right D maxillary & 0 & $\begin{array}{l}11 \\
(23.4 \%)\end{array}$ & $\begin{array}{l}33 \\
(70.2 \%)\end{array}$ & $\begin{array}{l}3 \\
(6.4 \%)\end{array}$ & $\begin{array}{l}3 \\
(6 \%)\end{array}$ & $\begin{array}{l}26 \\
(52 \%)\end{array}$ & $\begin{array}{l}21 \\
(42 \%)\end{array}$ & 0 & *** \\
\hline Right E maxillary & 0 & $\begin{array}{l}25 \\
(53.2 \%)\end{array}$ & $\begin{array}{l}22 \\
(46.8 \%)\end{array}$ & 0 & $\begin{array}{l}9 \\
(18 \%)\end{array}$ & $\begin{array}{l}34 \\
(68 \%)\end{array}$ & $\begin{array}{l}7 \\
(14 \%)\end{array}$ & 0 & *** \\
\hline $\begin{array}{l}\text { Right maxillary } \\
\text { segment }(C+D+E)\end{array}$ & 1 & 43 & 81 & 16 & 13 & 74 & 62 & 1 & *** \\
\hline Left $C$ maxillary & $\begin{array}{l}1 \\
(2.1 \%)\end{array}$ & $\begin{array}{l}4 \\
(8.5 \%)\end{array}$ & $\begin{array}{l}26 \\
(55.3 \%)\end{array}$ & $\begin{array}{l}16 \\
(34 \%)\end{array}$ & $\begin{array}{l}1 \\
(2 \%)\end{array}$ & $\begin{array}{l}12 \\
(24 \%)\end{array}$ & $\begin{array}{l}36 \\
(72 \%)\end{array}$ & $\begin{array}{l}1 \\
(2 \%)\end{array}$ & *** \\
\hline Left D maxillary & $\begin{array}{l}1 \\
(2.1 \%)\end{array}$ & $\begin{array}{l}8 \\
(17 \%)\end{array}$ & $\begin{array}{l}36 \\
(76.6 \%)\end{array}$ & $\begin{array}{l}2 \\
(4.3 \%)\end{array}$ & $\begin{array}{l}3 \\
(6 \%)\end{array}$ & $\begin{array}{l}22 \\
(44 \%)\end{array}$ & $\begin{array}{l}25 \\
(50 \%)\end{array}$ & 0 & *** \\
\hline Left E maxillary & $\begin{array}{l}1 \\
(2.1 \%)\end{array}$ & $\begin{array}{l}20 \\
(42.6 \%)\end{array}$ & $\begin{array}{l}26 \\
(55.3 \%)\end{array}$ & 0 & $\begin{array}{l}8 \\
(16 \%)\end{array}$ & $\begin{array}{l}35 \\
(70 \%)\end{array}$ & $\begin{array}{l}7 \\
(14 \%)\end{array}$ & 0 & *** \\
\hline $\begin{array}{l}\text { Left maxillary } \\
\text { segment }(C+D+E)\end{array}$ & 3 & 32 & 78 & 18 & 12 & 69 & 68 & 1 & *** \\
\hline Right C mandibular & 0 & $\begin{array}{l}8 \\
(17 \%)\end{array}$ & $\begin{array}{l}35 \\
(74.5 \%)\end{array}$ & $\begin{array}{l}4 \\
(8.5 \%)\end{array}$ & $\begin{array}{l}1( \\
2 \%)\end{array}$ & $\begin{array}{l}10 \\
(20 \%)\end{array}$ & $\begin{array}{l}39 \\
(78 \%)\end{array}$ & 0 & NS \\
\hline Right D mandibular & 0 & $\begin{array}{l}5 \\
(10.6 \%)\end{array}$ & $\begin{array}{l}42 \\
(89.4 \%)\end{array}$ & 0 & $\begin{array}{l}4 \\
(8 \%)\end{array}$ & $\begin{array}{l}20 \\
(40 \%)\end{array}$ & $\begin{array}{l}26 \\
(52 \%)\end{array}$ & 0 & *** \\
\hline Right E mandibular & 0 & $\begin{array}{l}15 \\
(31.9 \%)\end{array}$ & $\begin{array}{l}32 \\
(68.1 \%)\end{array}$ & 0 & $\begin{array}{l}6 \\
(12 \%)\end{array}$ & $\begin{array}{l}30 \\
(60 \%)\end{array}$ & $\begin{array}{l}14 \\
(28 \%)\end{array}$ & 0 & *** \\
\hline $\begin{array}{l}\text { Right mandibular } \\
\text { segment }(C+D+E)\end{array}$ & 0 & 28 & 109 & 4 & 11 & 60 & 79 & 0 & *** \\
\hline Left $\mathrm{C}$ mandibular & 0 & $\begin{array}{l}7 \\
(14.9 \%)\end{array}$ & $\begin{array}{l}35 \\
(74.5 \%)\end{array}$ & $\begin{array}{l}5 \\
(10.6 \%)\end{array}$ & $\begin{array}{l}1 \\
(2 \%)\end{array}$ & $\begin{array}{l}13 \\
(26 \%)\end{array}$ & $\begin{array}{l}36 \\
(72 \%)\end{array}$ & 0 & * \\
\hline Left D mandibular & 0 & $\begin{array}{l}8 \\
(17 \%)\end{array}$ & $\begin{array}{l}38 \\
(80.9 \%)\end{array}$ & $\begin{array}{l}1 \\
(2.1 \%)\end{array}$ & $\begin{array}{l}2 \\
(4 \%)\end{array}$ & $\begin{array}{l}21 \\
(42 \%)\end{array}$ & $\begin{array}{l}27 \\
(54 \%)\end{array}$ & 0 & *** \\
\hline Left E mandibular & 0 & $\begin{array}{l}19 \\
(40.4 \%)\end{array}$ & $\begin{array}{l}28 \\
(59.6 \%)\end{array}$ & 0 & $\begin{array}{l}9 \\
(18 \%)\end{array}$ & $\begin{array}{l}26 \\
(52 \%)\end{array}$ & $\begin{array}{l}15 \\
(30 \%)\end{array}$ & 0 & *** \\
\hline $\begin{array}{l}\text { Left mandibular } \\
\text { segment }(C+D+E)\end{array}$ & 0 & 34 & 101 & 6 & 12 & 60 & 82 & 0 & *** \\
\hline Total & 4 & 137 & 369 & 44 & 48 & 263 & 291 & 2 & *** \\
\hline
\end{tabular}

discrepancy: difference between maxillary and mandibular intercanine widths.

\section{Method error}

Fifteen randomly selected models were remeasured to calculate the method errors for all the variables, as described by Dahlberg. ${ }^{15}$ Any systematic error was determined by calculating the coefficients of reliability for all the variables, as suggested by Houston. ${ }^{16}$ Method errors ranged from 0.00 to $0.66 \mathrm{~mm}$. Corresponding coefficients of reliability ranged from 0.81 to 1.00. The reproducibility error for tooth abrasion scoring was also tested. Scores of the first and the second observations were statistically compared by means of a kappa test with Yates's correction in order to calculate the degree of reproducibility of concern. The result (0.94) expressed a high rate of reproducibility.

\section{Statistical analysis}

Descriptive statistics comprising prevalence rates for different abrasion scores were calculated.

The data from wear ratings and casts measurements of the two groups were compared separately for boys and girls using a nonparametric test (Mann-Whitney U-test) for independent samples ( $\mathrm{P}<.05)$. All statistical computations were performed with a Statistical Package for the Social Studies (SPSS, Version 12.0, SPSS Inc, Chicago, Ill). 


\begin{tabular}{|c|c|c|c|c|c|c|c|c|c|c|c|c|}
\hline & \multicolumn{12}{|c|}{ Females } \\
\hline & \multicolumn{5}{|c|}{$1950 \mathrm{~s}$} & \multicolumn{5}{|c|}{$1990 \mathrm{~s}$} & \multirow[b]{2}{*}{$z$} & \multirow[b]{2}{*}{ Sig } \\
\hline & $N$ & Min & Max & Mean & S.D. & $\mathrm{N}$ & Min & Max & Mean & S.D. & & \\
\hline Posterior maxillary right segment & 44 & 21.0 & 24.5 & 22.54 & .74 & 46 & 20.0 & 25.0 & 22.66 & 1.06 & -0.92 & NS \\
\hline Anterior maxillary right segment & 44 & 11.5 & 17.0 & 14.28 & 1.26 & 45 & 9.5 & 17.5 & 14.86 & 1.68 & -2.11 & * \\
\hline Upper interincisal diastema & 44 & 0.0 & 4.0 & 1.27 & 1.07 & 45 & 0.0 & 4.5 & 1.07 & 1.14 & -1.05 & NS \\
\hline Anterior maxillary left segment & 44 & 11.0 & 17.0 & 14.34 & 1.59 & 45 & 10.0 & 17.5 & 14.94 & 1.39 & -1.68 & NS \\
\hline Posterior maxillary left segment & 44 & 21.0 & 27.5 & 22.65 & 1.10 & 46 & 20.0 & 25.0 & 22.58 & 1.04 & -0.12 & NS \\
\hline Maxillary intercanine width & 44 & 21.5 & 30.0 & 25.99 & 2.05 & 46 & 20.0 & 30.0 & 25.95 & 2.39 & -0.17 & NS \\
\hline Maxillary intermolar width & 44 & 41.0 & 48.5 & 44.51 & 2.03 & 46 & 38.5 & 48.5 & 43.42 & 2.46 & -2.31 & * \\
\hline Mesiodistal size 12 & 24 & 5.5 & 9.0 & 7.06 & 0.76 & 37 & 5.5 & 8.0 & 6.86 & 0.67 & -0.76 & NS \\
\hline Mesiodistal size 11 & 44 & 6.5 & 10.0 & 8.73 & 0.61 & 45 & 6.0 & 10.0 & 8.57 & 0.74 & -1.34 & NS \\
\hline Mesiodistal size 21 & 44 & 6.5 & 10.0 & 8.73 & 0.61 & 45 & 6.0 & 10.0 & 8.57 & 0.74 & -1.34 & NS \\
\hline Mesiodistal size 22 & 26 & 5.5 & 9.0 & 7.06 & 0.71 & 37 & 5.5 & 8.0 & 6.86 & 0.67 & -0.72 & NS \\
\hline Maxillary available space & 24 & -6.5 & 4.5 & -0.83 & 3.24 & 38 & -6.0 & 6.0 & 0.60 & 2.86 & -1.63 & NS \\
\hline Posterior mandibular left segment & 44 & 21.5 & 26.0 & 23.10 & 1.08 & 46 & 21.0 & 26.5 & 23.11 & 1.13 & -0.29 & NS \\
\hline Anterior mandibular left segment & 44 & 7.0 & 13.0 & 10.89 & 1.10 & 46 & 8.5 & 13.5 & 10.90 & 1.13 & -0.25 & NS \\
\hline Mandibular interincisal diastema & 44 & 0.0 & 2.0 & 0.14 & 0.41 & 46 & 0.0 & 1.5 & 0.17 & 0.35 & -1.14 & NS \\
\hline Anterior mandibular right segment & 44 & 7.5 & 13.0 & 10.92 & 0.97 & 46 & 8.0 & 13.5 & 11.17 & 0.97 & -1.29 & NS \\
\hline Posterior mandibular right segment & 44 & 21.5 & 25.5 & 23.15 & 1.15 & 46 & 21.0 & 25.5 & 23.09 & 1.07 & -0.21 & NS \\
\hline Mandibular intercanine width & 44 & 22.0 & 32.0 & 25.31 & 2.03 & 46 & 21.5 & 30.5 & 25.38 & 2.24 & -0.44 & NS \\
\hline Mandibular intermolar width & 44 & 41.0 & 50.0 & 45.77 & 2.24 & 46 & 39.5 & 54.5 & 45.62 & 2.63 & -0.83 & NS \\
\hline Mesiodistal size 32 & 38 & 5.5 & 7.0 & 6.05 & 0.40 & 41 & 5.0 & 7.0 & 6.08 & 0.50 & -0.52 & NS \\
\hline Mesiodistal size 31 & 44 & 4.5 & 6.5 & 5.62 & 0.40 & 46 & 5.0 & 7.0 & 5.67 & 0.56 & -0.09 & NS \\
\hline Mesiodistal size 41 & 44 & 4.5 & 6.5 & 5.64 & 0.39 & 46 & 5.0 & 7.0 & 5.67 & 0.56 & -0.02 & NS \\
\hline Mesiodistal size 42 & 37 & 5.5 & 7.0 & 6.04 & 0.41 & 41 & 5.0 & 7.0 & 6.08 & 0.50 & -0.62 & NS \\
\hline Mandibular available space & 37 & -6.0 & 4.0 & -1.34 & 2.39 & 43 & 0.0 & 17.0 & 4.63 & 4.52 & -0.89 & NS \\
\hline ATID & 44 & -3.5 & 5.0 & 0.68 & 1.89 & 46 & -4.5 & 4.0 & 0.56 & 2.17 & -0.05 & NS \\
\hline PTID & 44 & -4.0 & 1.0 & -1.26 & 1.16 & 46 & -8.0 & -0.5 & -2.2 & 1.61 & -2.75 & *** \\
\hline
\end{tabular}

\section{RESULTS}

\section{Tooth abrasion}

Descriptive statistics and statistical comparisons for the two examined groups are given in Tables 1 and 2. The comparison of the degree of abrasion for single teeth showed significant differences between the 50sG and the 90sG for almost all examined teeth, which appeared to be significantly more abraded in the 50sG.
A significant smaller degree of abrasion in left and right, upper and lower posterior segments of the dental arches was found in the 50sG when contrasted with the 90sG. Absence of tooth wear (score 0) was observed in only four out of 1,200 teeth $(0.33 \%)$ in the $50 \mathrm{sG}$, whereas 60 out of 1,200 teeth (5\%) were considered free of tooth wear in the 90sG. Extensive tooth wear (score 3) was assessed in 120 of 1,200 teeth $(10 \%)$ in the $50 \mathrm{sG}$ and in only 18 out of $1200(1.5 \%)$ in the 90sG.

\section{Dental arch dimensions}

Descriptive statistics and statistical comparison for the examined groups are reported in Tables 3 and 4. Both boys and girls of the 90sG showed significantly smaller maxillary intermolar width when compared with the 50sG. PTID was significantly minor in girls of the 90sG. A reduction of the anterior segments of the 


\begin{tabular}{|c|c|c|c|c|c|c|c|c|c|c|c|c|}
\hline & \multicolumn{12}{|c|}{ Males } \\
\hline & \multicolumn{5}{|c|}{$1950 \mathrm{~s}$} & \multicolumn{5}{|c|}{$1990 \mathrm{~s}$} & \multirow[b]{2}{*}{ Z } & \multirow[b]{2}{*}{ Sig } \\
\hline & $\mathrm{N}$ & Min & Max & Mean & S.D. & $\mathrm{N}$ & Min & Max & Mean & S.D. & & \\
\hline Posterior maxillary right segment & 39 & 21.0 & 25.0 & 23.27 & 1.03 & 38 & 21.5 & 25.0 & 22.97 & 0.88 & -1.51 & NS \\
\hline Anterior maxillary right segment & 37 & 11.0 & 18.5 & 14.96 & 1.64 & 37 & 10.5 & 17.5 & 15.08 & 1.59 & -0.54 & NS \\
\hline Maxillary interincisal diastema & 37 & 0.0 & 5.0 & 1.41 & 1.25 & 36 & 0.0 & 4.0 & 1.15 & 1.09 & -0.86 & NS \\
\hline Anterior maxillary left segment & 38 & 11.0 & 18.5 & 15.12 & 1.84 & 37 & 12.0 & 17.5 & 15.04 & 1.41 & -0.26 & NS \\
\hline Posterior maxillary left segment & 39 & 16.5 & 25.0 & 22.89 & 1.47 & 38 & 21.0 & 25.0 & 22.87 & 0.98 & -0.72 & NS \\
\hline Maxillary intercanine width & 39 & 22.5 & 34.5 & 27.09 & 2.48 & 38 & 22.0 & 31.0 & 26.61 & 1.85 & -0.55 & NS \\
\hline Maxillary intermolar width & 39 & 40.5 & 51.0 & 45.67 & 1.98 & 38 & 38.0 & 50.5 & 44.38 & 2.37 & -2.62 & *** \\
\hline Mesiodistal size 12 & 23 & 6.0 & 8.0 & 6.96 & 0.67 & 29 & 5.5 & 9.0 & 7.10 & 0.70 & -0.81 & NS \\
\hline Mesiodistal size 11 & 32 & 8.0 & 10.0 & 8.98 & 0.47 & 35 & 7.0 & 9.5 & 8.71 & 0.55 & -1.95 & NS \\
\hline Mesiodistal size 21 & 32 & 8.0 & 10.0 & 8.98 & 0.47 & 35 & 7.0 & 9.5 & 8.71 & 0.55 & -1.95 & NS \\
\hline Mesiodistal size 22 & 23 & 6.0 & 8.0 & 7.00 & 0.64 & 29 & 5.5 & 9.0 & 7.09 & 0.70 & -0.51 & NS \\
\hline Maxillary available space & 22 & -6.5 & 8.0 & 0.30 & 3.97 & 29 & -5.0 & 7.5 & 0.52 & 3.25 & -0.12 & NS \\
\hline Posterior mandibular left segment & 39 & 22.0 & 26.0 & 23.77 & 1.14 & 38 & 22.0 & 25.0 & 23.68 & 0.93 & -0.10 & NS \\
\hline Anterior mandibular left segment & 39 & 9.0 & 14.0 & 11.33 & 1.03 & 38 & 10.0 & 16.0 & 11.45 & 1.16 & -0.17 & NS \\
\hline Mandibular interincisal diastema & 39 & 0.0 & 1.0 & 0.13 & 0.250 & 38 & 0.0 & 1.5 & 0.25 & 0.43 & -0.93 & NS \\
\hline Anterior mandibular right segment & 39 & 8.5 & 13.0 & 11.18 & 1.07 & 38 & 9.0 & 16.0 & 11.36 & 1.29 & -0.32 & NS \\
\hline Posterior i mandibular right segment & 39 & 22.0 & 26.0 & 23.86 & 1.09 & 38 & 22.0 & 26.0 & 23.76 & 1.00 & -0.42 & NS \\
\hline Mandibular intercanine width & 39 & 23.0 & 31.0 & 26.28 & 1.86 & 38 & 22.0 & 30.0 & 25.79 & 1.93 & -0.96 & NS \\
\hline Mandibular intermolar width & 38 & 44.0 & 53.5 & 46.92 & 2.08 & 38 & 42.0 & 50.0 & 46.20 & 2.11 & -1.15 & NS \\
\hline Mesiodistal size 32 & 35 & 5.5 & 7.0 & 6.39 & 0.42 & 34 & 5.5 & 7.0 & 6.29 & 0.48 & -0.90 & NS \\
\hline Mesiodistal size 31 & 39 & 5.0 & 6.5 & 5.90 & 0.42 & 37 & 5.0 & 6.5 & 5.74 & 0.44 & -1.61 & NS \\
\hline Mesiodistal size 41 & 39 & 5.0 & 6.5 & 5.90 & 0.42 & 37 & 5.0 & 6.5 & 5.74 & 0.44 & -1.61 & NS \\
\hline Mesiodistal size 42 & 36 & 5.5 & 7.0 & 6.38 & 0.42 & 34 & 5.5 & 7.0 & 6.29 & 0.48 & -0.81 & NS \\
\hline Mandibular available space & 35 & -5.0 & 4.0 & -1.94 & 2.27 & 34 & -5.5 & 5.0 & -0.90 & 2.30 & -2.00 & NS \\
\hline ATID & 34 & 0.0 & 21.0 & 6.77 & 5.07 & 34 & 0.0 & 13.5 & 4.31 & 4.45 & -0.29 & NS \\
\hline PTID & 39 & -4.5 & 5.5 & 0.81 & 2.24 & 38 & -2.5 & 3.5 & 0.82 & 1.43 & -1.16 & NS \\
\hline
\end{tabular}

upper arch in girls of the 90sG on the left side was found, but the difference is clinically not relevant. No differences were found for all the other examined values.

\section{DISCUSSION}

The study of the transversal dental arch dimensions in relationship with tooth wear in the primary dentition is relatively unique and the findings of our analysis provide useful information concerning
Italian young people in two samples separated by 30 years. The authors, in order to fulfil a more valid investigation, have selected children coming from a restricted geographical area with a limited ethnically heterogeneous population.

Various authors have reported an increased prevalence of malocclusion during the last few hundred years. ${ }^{4,17-19}$

The 'disuse theory' described by Corruccini and Whitley ${ }^{20}$ explains the increasing diffusion of malocclusions in the last decades giving great importance to decreased function of the masticatory system, which should be responsible for insufficient development of the jaws. Similar considerations were made by Price $^{3}$ who studied Gaelic communities in the Outer Hebrides, Eskimos and Indians of North America, Melanesian and Polynesian South Sea Islanders, African tribes, Australian aborigines, New Zealand Maori, and the 
Indians of South America, observing a very poor incidence of dental diseases and malocclusions. Specifically in Eskimos, he observed perfect occlusions until the contact with industrialised societies ${ }^{21}$ and later the incidence of malocclusion increased to $50 \%$ with the introduction of a diet based on processed foods. ${ }^{22}$

Different explanations were given by Begg, ${ }^{23}$ who suggested that the loss of interproximal hard tissues, due to attrition, could be able to provide enough space for permanent teeth to achieve an adequate alignment.

The findings of our study indicate that untreated subjects, in the mixed dentition, observed in the last ten years, show a significant reduction of the width of the upper arch when compared with subjects observed 40 years ago in accordance with the findings of Lindsten et al. ${ }^{6-8}$

This can be interpreted as a sign of lack of function in modern subjects as a consequence of processed food, on the basis of the positive association between masticatory function and the development of the jaws. This association has been experimentally demonstrated on animal samples in numerous studies.

Beecher and Corruccini ${ }^{24}$ made an association between moderate differences in the hardness of the diet and the narrowing of the maxillary arch in the rats. They suggested that mediolateral maxillary growth depends on the stimulation of the muscles provided by rough elements in the diet. The same authors found the equivalent results with a population of rhesus macaques, baboons and other non-human primates. ${ }^{25-27}$

Bouvier and Hylander ${ }^{28}$ microscopically examined the same sample and found fewer secondary Haversian systems in the mandibular corpus. Ciochon et al. ${ }^{29}$ found a $25 \%$ greater size of the deep masseter, superficial masseter and temporalis weight in minipigs fed with hard food in comparison with minipigs supplied with soft food. Another important cause of the narrowing of the upper arch in modern populations, is the amplified prevalence of mouth breathing ${ }^{30}$ with a consequent respiratory disease increase such as allergy and asthma. ${ }^{31-34}$

Lindsten et $a l .{ }^{35}$ suggested that many contemporary children frequently chew gum, and for this reason, a change in the dietary consistency cannot be ruled out as a causative factor of the narrowing of the maxilla. Consequently, mouth breathing has to be considered a major cause of the narrowing of the maxillary arch in modern populations. A tendency toward a reduction of the posterior transverse intermolar dimension was found in children born in the 1990s in relation to their coetaneous born in the 1950s: PTID is a fundamental sign of various malocclusions. Tollaro et al. ${ }^{36}$ have shown that a negative PTID exists in dental arches with Class II malocclusion (3.4 mm on average) and seemingly normal buccal relationships. The stimulation of the muscular structures due to hard and fibrous food allows a major development of the dental arches, resulting in a greater functional stimulation of the masticatory muscles and an increased occlusal wear. ${ }^{37,38}$ There was no difference between the two groups for the dimensions of the posterior segments, which contrasts with the results of Lindsten et al. ${ }^{5}$ who found larger spaces in the posterior segment in children born in the 1980s when compared with those born in the 1950s. They hypothesised that there was a change in the lateral arch space conditions during the last decades because of the decline in caries prevalence occurring in the same period. The different findings of our study may be due to the selection of the samples, because the absence of caries was an inclusionary criterion for subjects involved in our study. The other causes of loss of proximal tooth material of posterior teeth, such as interproximal wear, are lacking in modern populations and are not able to cause a reduction of the transversal length of the posterior segments of the arch in the mixed dentition. The interproximal tooth wear represent a condition related with the dietary consistence. ${ }^{39}$

Tooth abrasion can be considered as a physiological condition in the deciduous dentition, with its pattern indicating the functional relationship between the dental arches. ${ }^{40}$ The degree of tooth abrasion differs in different populations and ethnic groups in relation to dietary habits. Eskimos, North American Indians, and Greek mountaineers, for instance, showed a great extent of abrasion as a result of coarse and rough food diets. ${ }^{10}$

Occlusal abrasion allows an adequate sliding between the dental arches, which is a necessary condition in order to achieve a functionally correct development of the masticatory system. ${ }^{39,40}$

The findings of the present study reveal that untreated subjects in the mixed dentition born in the 1990s show a significantly lesser degree of occlusal abrasion of posterior deciduous teeth when compared with subjects born in the 1950s. Extensive wear into the dentine (score 3) was observed in only $1.5 \%$ of examined teeth in the current sample, a percentage which is similar to the one assessed by Knight et al. (2.7\%). Subjects who were born in the 1950s showed a larger number of teeth with score 3 (10.25\%).

The wear of occlusal surfaces of primary teeth is a physiological condition in the deciduous and mixed dentitions. ${ }^{10}$ The lack of dental wear is one of the recognised aetiologic factors of malocclusions. Unworn cusps can cause dental interferences leading to forced guidance of mandible in an incorrect position, in the sagittal or transverse plane..$^{11,39,41}$

Past investigations identified a large amount of tooth wear in primitive populations, where the prevalence of malocclusions was lower when compared with current groups. ${ }^{10,42-52}$

Previous studies have shown an increasing prevalence for certain malocclusions in the past 30 years of last century., 5 The aim of this study was to test whether there has been a significant increase or decrease in the amount of wear of deciduous teeth during the same period, due to an occlusal aspect, possibly correlated to malocclusions.

Previous studies ${ }^{5,6}$ about the secular trend of malocclusions in recent years, advocated that the change in dietary habits that occurred in the past decades, appears to be linked to the increased prevalence of occlusal disorders. The masticatory activity decrease as a consequence of the increased use of processed food could also be responsible of inadequate wear of deciduous teeth along with underdeveloped jaws.

Dental interferences and forced guidance of mandible to an incorrect position in both the sagittal or transverse planes result from a lack of physiological changes in the dental arches. ${ }^{11,41}$

On the contrary, the use of hard and fibrous food is associated with a greater diameter of the dental arches, with 
increased wear of occlusal surfaces and with a smaller probability of occurrence of anomalous occlusal patterns. ${ }^{10}$ The simultaneous presence of underdeveloped jaws and unworn teeth may be a cause of dental interferences and forced guidance of the mandible in an incorrect position in the sagittal or transverse plane, with a consequential malocclusion. ${ }^{11,4}$

\section{CONCLUSION}

The sample of Italian children selected, coming from the geographical area of Tuscany and born in the 1990s, show significantly reduced occlusal tooth wear and transverse intermolar maxillary width in comparison with a sample of children born in the 1950s and coming from the same geographical region.

This association can partially explain the greater risk of developing malocclusions in contemporary children compared with children living 35 years before.

1. Lombardi A V. The adaptive value of dental crowding: a consideration of the biologic basis of malocclusion. Am J Orthod 1982; 81: 38-42.

2. Hunt E E Jr. Malocclusion and civilization. Am J Orthod 1961; 47: 406-422.

3. Price W A. Nutrition and physical degeneration. New Canaan, Conn: Keats Publishing, Inc, 1943.

4. Corruccini R S. An epidemiologic transition in dental occlusion in world populations. Am J Orthod 1984; 86: 419-426.

5. Lindsten $\mathrm{R}, \mathrm{Ogaard} \mathrm{B}$, Larsson E. Difference in dental lateral arch length between 9 -year-olds born in the 1960s and the 1980s. Am J Orthod Dentofacial Orthop 2000: 117: 663-668.

6. Lindsten $\mathrm{R}$, Ogaard B, Larsson E. Transversal dental arch dimensions in 9-year-old children born in the 1960s and the 1980s. Am J Orthod Dentofacial Orthop 2001; 120: 576-584.

7. Lindsten $\mathrm{R}$, Ogaard B, Larsson E, Bjerklin K. Transverse dental and dental arch depth dimensions in the mixed dentition in a skeletal sample from the 14th to the 19th century and Norwegian children and Norwegian Sami children of today. Angle Orthod 2002: 72: 439-448.

8. Lindsten R. Secular changes in tooth size and dental arch dimensions in the mixed dentition. Swed Dent J Supp/ 2003; 157: 1-89.

9. Marinelli A, Alarashi M, Defraia E, Antonini A, Tollaro Tooth wear in the mixed dentition: a comparative study between children born in the 1950s and the 1990s. Angle Orthod 2005: 75: 340-343.

10. Moyers R E. Handbook of orthodontics, 4th ed. p 110 Chicago, III: Year Book Medical Publishers, 1988.

11. Tollaro I, Defraia E, Marinelli A, Alarashi M.
Tooth abrasion in unilateral posterior crossbite in the deciduous dentition. Angle Orthod 2002: 72: 426-430.

12. Knight D J, Leroux B G, Zhu C, Almond J, Ramsay D S. A longitudinal study of tooth wear in orthodontically treated patients. Am J Orthod Dentofacial Orthop 1997; 112: 194-202.

13. Nystrom M, Kononen M, Alaluusna S, Evalahti M, Vartiovaara J. Development of horizontal tooth wear in maxillary anterior teeth from five to 18 years of age. J Dent Res 1990; 69: 1765-1770.

14. Ash M M. Wheeler's dental anatomy, physiology and occlusion, 6th ed. pp 47-49. Philadelphia, PA: WB Saunders, 1984

15. Dahlberg G. Statistical methods for medical and biological students. New York, NY: Interscience Publications, 1940.

16. Houston W J. The analysis of errors in orthodontic measurements. Am J Orthod 1983; 83: 382-390.

17. Helm S, Prydsö U. Prevalence of malocclusion in a medieval and modern Danes contrasted. Scand J Dent Res 1979; 87: 91-97.

18. Varrela J. Occurrence of malocclusion in attritive environment: a study of a skull sample from southwest Finland. Scand J Dent Res 1990; 98: 242-247.

19. Weiland F J, Jonke E, Bantleon H P. Secular trends in malocclusion in Austrian men. Eur J Orthod 1997; 19: 355-359.

20. Corruccini R S, Whitley L D. Occlusal variation in a rural Kentucky community. Am J Orthod 1981; 79: 250-262.

21. Price W A. Eskimo and Indian field studies in Alaska and Canada. J Am Dent Assoc 1936; 23: 417-437.

22. Wood B F. Malocclusion in the modern Alaska Eskimo. Am J Orthod 1971; 60: 344-354.

23. Begg P. Begg orthodontic theory and technique. Philadelphia, Pa: WB Saunders Company, 1965

24. Beecher R M, Corruccini R S. Effects of dietary consistency on craniofacial and occlusal development in the rat. Angle Orthod 1981; 51: 61-69.

25. Beecher R M, Corruccini R S. Effects of dietary consistency on maxillary arch breadth in macaques. J Dent Res 1981; 60: 68.

26. Beecher R M, Corruccini R S. Occlusofacial morphological integration lowered in baboons raised on soft diet. J Craniofac Genet Dev Biol 1984; 4: 135-142.

27. Beecher R M, Corruccini R S. Occlusal variation related to soft diet in a nonhuman primate. Science 1982; 218: 74-76.

28. Bouvier M, Hylander W L. Effect of bone strain on cortical bone structure in macaques (Macaca mulatta). J Morphol 1981; 167: 1-12.

29. Ciochon R L, Nisbett R A, Corruccini R S. Dietary consistency and craniofacial development related to masticatory function in minipigs. J Craniofac Genet Dev Biol 1997; 17: 96-102.

30. Sly R M. Changing prevalence of allergic rhinitis and asthma. Ann Allergy Asthma Immunol 1999 82: $233-248$

31. Gross A M, Kellum G D, Franz D, Michas K et al. A longitudinal evaluation of open mouth posture and maxillary arch width in children. Angle Orthod 1994; 64: 419-424.

32. Gross A M, Kellum G D, Michas C, Franz D et al. Open-mouth posture and maxillary arch width in young children: a three-year evaluation. Am J Orthod Dentofacial Orthop 1994; 106: 635-640.

33. Corruccini R S, Flander L B, Kaul S S. Mouth breathing, occlusion and modernization in a North Indian population: an epidemiologic study. Angle Orthod 1985; 55: 190-196.

34. Corruccini R S, Kaul S S. The epidemiological transition and anthropology of minor chronic not-infectious diseases. Med Anthropol 1983; 7: 36-50.

35. Lindsten $R, O$ gaard $B$, Larsson E. Transversal dental arch dimensions in 9-year-old children born in the 1960s and the 1980s. Am J Orthod Dentofacial Orthop 2001; 120: 576-584.

36. Tollaro I, Baccetti T, Franchi L, Tanasescu C D. Role of posterior transverse interarch discrepancy in Class II division 1 malocclusion during the mixed dentition phase. Am J Orthod Dentofacial Orthop 1996; 110: 417-422.

37. Almond J R, Leroux B G, Knight D J, Ramsay D S. Craniofacial morphology and tooth wear: a longitudinal study of orthodontic patients. Angle Orthod 1999; 69: 7-13.

38. Alamoudi N. The prevalence of crowding, attrition, midline discrepancies and premature tooth loss in the primary dentition of children in Jeddah, Saudi Arabia. J Clin Pediatr Dent 1999; 24: 53-58.

39. Muller H. Introduction a la Pratique de l'Ortopedie Dentofaciale et de l'Ortodontie. p 51. Paris: Ed Ageco, 1970.

40. Van Der Linden F P G M, Duterloo H S. Development of the human dentition, an atlas. Hagerstown, MD: Harper and Row, 1976.

41. Moyers R E, Wainright R. Skeletal contributions to occlusal development. In McNamara J A J (ed). The biology of occlusal development, Monograph 7. Craniofacial Growth Series. pp 89-111. Ann Arbor, Mich: Center for Human Growth and Development, University of Michigan, 1977.

42. Campbell T D. Observations on the teeth of Australian aborigines, River Diamentia. Aus J Dent 1938; 42: 121-125.

43. Campbell T D, Lewis A J. The aborigines of South Australia: dental observations recorded at Ooldea. Aust Dent J 1926; 30: 371-376.

44. Corruccini R S, Townsend G C, Brown T. Occlusal variation in Australian aboriginals. Am J Phys Anthropol 1990; 82: 257-265.

45. Davies T G, Pedersen P 0. The degree of attrition of the deciduous teeth and first permanent molars of primitive and urbanized Greenland natives. Br Dent J 1955; 99: 35-43.

46. Lunt D A. The dentition in a group of mediaeval Scottish children. Br Dent J 1972; 132: 443-446.

47. Helm S. Etiology and treatment need of malocclusion. J Can Dent Assoc 1979; 12: 673-676.

48. Shaw J C M. The teeth, the bony palate and the mandible in the Bantu Races of South Africa. London: Bale, Sons and Danielson, 1931.

49. Miles A E. The dentition of Anglo-Saxons. Proc $R$ Soc Med 1969; 62: 1311-1315.

50. Lysell L. Qualitative and quantitative determination of attrition and the ensuing tooth migration. Acta Odontol Scand 1958; 16: 267-292.

51. Hinton R J. Differences in interproximal and occlusal tooth wear among prehistoric Tennessee Indians: implications for masticatory functions. Am J Phys Anthropol 1982; 57: 103-115.

52. Whittaker D K, Ryan S, Weeks K, Murphy W M. Patterns of approximal wear in cheek teeth of a Romano-British population. Am J Phys Anthropol 1987: 73: 389-396. 